\title{
PENGARUH GAYA BELAJAR MATA KULIAH ARITMATIKA (JARI MATIKA DAN SEMPOA) TERHADAP KEMAMPUAN KOMUNIKASI MATEMATIS
}

\author{
Anwar Ardani ${ }^{1)}$, Dian Purwaningsih ${ }^{2)}$ \\ ${ }^{1 / 2)}$ Universitas Peradaban \\ anwarardani3@gmail.com,dian.purwaningsih24@yahoo.com
}

\begin{abstract}
Abstrak
Tujuan penelitian ini untuk mengetahui pengaruh gaya belajar terhadap kemampuan komunikasi matematis. Penelitian ini bersifat konklusif bertujuan menjelaskan pengaruh antar variabel yang dibedakan menjadi variabel independen sebagai variabel penyebab dan variabel dependen sebagai variabel yang menjadi akibat. Dalam penelitian ini dilakukan analisis untuk mengetahui pengaruh gaya belajar terhadap kemampuan komunikasi matematis, dan uji analisis regresi untuk mengetahui pengaruh gaya belajar terhadap kemampuan komunikasi matematis dapat disimpulkan bahwa ada pengaruh gaya belajar terhadap kemampuan komunikasi matematis mahasiswa.
\end{abstract}

Kata Kunci: Gaya Belajar, Aritmatika, Kemampuan komunikasi matematis

\begin{abstract}
The purpose of this study was to determine the effect of learning styles on mathematical communication ability. This study is conclusive aiming to explain the influence between variables that are divided into independent variables as the causal variable and the dependent variable as the variable that is the result. In this study an analysis was conducted to determine the effect of learning styles on mathematical communication ability, and the regression analysis test to determine the effect of learning styles on mathematical communication ability can be concluded that there is an influence of learning styles on students' mathematical communication ability.
\end{abstract}

Key word: Learning Style, Arithmetic, Mathematical communication ability.

\section{PENDAHULUAN}

Gaya belajar merupakan cara belajar mahasiswa dalam memahami pengetahuan yang sedang dipelajari. Menurut De Potter \& Hernacki (2007) ada tiga gaya belajar yaitu 1) gaya belajar visual, 2) gaya belajar auditorial, dan 3) gaya belajar kinestetik. Gaya belajar visual adalah cara belajar yang mengandalkan penglihatan untuk dapat memahami informasi, gaya belajar auditorial adalah cara mudah dalam belajar yang mengandal $\neg$ kan pendengaran untuk bisa mengingat dan memahami suatu informasi, sedangkan gaya belajar kinestetik adalah cara belajar yang dilakukan dengan bergerak, bekerja dan menyentuh yaitu mengandalkan praktik/gerakan anggota tubuh. Diharapkan mahasiswa belajar dengan menggunakan kombinasi dari ketiga gaya belajar ini, akan tetapi kebanyakan mahasiswa akan lebih cenderung pada salah satu di antara ketiganya yang mengakibatkan rendahnya keberhasilan siswa dalam memahami pengetahuan yang sedang dipelajari. Namun kenyataannya 
banyak mahasiswa yang kurang mampu dalam menyampaikan pemikirannya atau mengkomuikasikan hasil pikirannya baik secara lisan maupun tulisan. Kurangnya kemampuan komunikasi dalam pembelajaran matematika merupakan faktor penghambat keberlangsungan pembelajaran.

Komunikasi menjadikan adanya interaksi antara mahasiswa dan dosen ataupun mahasiswa dengan mahasiswa. Menurut Suprapto (2009:10), komunikasi adalah proses penyampaian suatu pernyataan oleh seorang kepada orang lain. Kemampuan komunikasi matematis merupakan kemampuan atau kesanggupan mahasiswa dalam menyampaikan pemahaman materi matematika (dalam hal ini aritmatika) yang telah dipelajari.Komunikasi matematis secara tidak langsung dapat mempertajam pemahaman matematis NCTM (2000), Sumarmo (2000).

Aritmatika merupakan salah satu mata kuliah dalam kurikulum jurusan PGSD yang mengintegrasikan sektor pendidikan dengan sektor pelatihan yang sangat diperlukan dalam dunia kerja khususnya bagi calon guru sekolah dasar.Aritmatika mengenalkan lebih lanjut metode dan teknik berhitung pada operasi penjumlahan, pengurangan, perkalian dan pembagian.Metode dan teknik berhitung pada matakuliah aritmatika menggunakan jari (jarimatika) dan alat hitung sempoa yang digunakan dalam pembelajaran. Tujuan penelitian ini untuk mengetahui pengaruh gaya belajar terhadap kemampuan komunikasi matematis

\section{LANDASAN TEORI \\ Gaya Belajar}

Belajar merupakan suatu kegiatan yang menjadikan seseorang yang tidak tahu menjadi tahu setelah melaksanakan kegiatan belajar. Cara seorang menyerap, mengatur dan mengolah informasi merupakan suatu gaya belajar seorang dalam memahami sesuatu. Menurut DePotter dan Hernacki (2007: 111-112), gaya belajar adalah kombinasi dari bagaimana ia menyerap, dan kemudian mengatur serta mengolah informasi. Gaya belajar adalah cara yang konsisten yang dilakukan oleh seorang siswa dalam menangkap stimulus atau informasi, cara mengingat, berpikir, dan memecahkan soal Nasution (2008), Ramlah \& Hamzah (2014). Ada tiga gaya belajar yaitu gaya belajar visual (penglihatan), gaya belajar auditorial (pendengaran), dan gaya belajar kinestetik (sentuhan dan gerak) yang biasa disingkat dengan VAK (De Potter dan Hernacki, 2007 : 116-118).

\section{Aritmatika (jarimatika dan sempoa)}

Jarimatika merupakan salah satu cara melakukan operasi hitung. Metode yang digunakan untuk menerapkan jarimatika dalam pelaksanaan pembelajaran matematika adalah metode praktek. Metode ini bertujuan untuk membantu anak menjadi jelas dan mudah dalam berhitung. Teknik jarimatika adalah salah satu menghitung matematika dengan alat bantu jari. Menurut Prasetyo, dkk (2009: 19) mengatakan bahwa jarimatika merupakan salah satu teknik menghitung cepat dan akurat yang paling berkembang pesat dan sangat diminati banyak orang. Teknik jarimatika adalah suatu cara menghitung matematika dengan 
menggunakan alat bantu jari. Jarimatika merupakan salah satu teknik berhitung cepat dalam matematika.

Sedangkan sempoa menurut Prasetyono (2009:258) menjelaskan bahwa dekak-dekak (sempoa) merupakan alat yang terbuat dari kayu dan manik-manik yang bisa digeser. Sempoa dapat digunakan untuk melakukan operasi aritmatika seperti penjumlahan, pengurangan, perkalian dan pembagian.

\section{Kemampuan Matematis}

\section{Komunikasi}

Komunikasi merupakan suatu hal yang sangat penting untuk menguatkan pemahaman orang akan sesuatu. Menurut Theodorson dan Thedorson (Suprapto, 2009:6), komunikasi adalah penyebaran informasi, ide-ide sebagai sikap atau emosi dari seseorang kepada orang lain terutama melalui simbol-simbol. Indikator komunikasi matematis penelitian ini mengacu pada NCTM (1989 : 214), sedangkan rubik penelitian dimodifikasi berdasakan kebutuhan penelitian

\section{METODE PENELITIAN Jenis Penelitian}

Penelitian ini bersifat konklusif bertujuan menjelaskan pengaruh antar variabel yang dibedakan menjadi variabel independen sebagai variabel penyebab dan variabel dependen sebagai variabel yang menjadi akibat.

\section{Subyek Penelitian}

Subyek Penelitian ini adalah mahasiswa jurusan Pendidikan Guru Sekolah Dasar (PGSD) Universitas Peradaban.

\section{Tempat Penelitian}

Penelitian ini dilaksanakan di Universitas Peradaban tahun ajaran 2017/2018.

\section{Instrumen Penelitian}

Instrumen penelitian yang digunakan yaitu: angket, observasi, wawancara dan tes.

\section{Teknik Pengumpulan Data}

Teknik pengumpulan data penelitian ini sebagai berikut: a) metode angket, yaitu merupakan suatu pengumpulan data yang memberikan atau menyebarkan daftar pertanyaan kepada mahasiswa. Metode angket digunakan untuk mengelompokkan gaya belajar bedasarkan klasifikasi gaya belajar; b) metode wawancara yaitu merupakan tanya jawab yang dilakukan secara langsung kepada subyek penelitian. Metode wawancara digunakan untuk mengetahui kemampuan komunikasi matematis; c) observasi, yaitu merupakan pengumpulan data yang dilakukan dengan pengamatan langsung kepada objek penelitian, d) metode tes, yaitu merupakan pertanyaan yang dilakukan secara lisan kepada subyek penelitian sesuai dengan indikator kemampuan komunikasi matematis.

\section{Teknik Analisi Data}

Analisis data dalam penelitian ini menggunakan uji regresi linear.

\section{HASIL PENELITIAN}

Penelitian ini dilakukan analisis untuk mengetahui pengaruh gaya belajar terhadap kemampuan komunikasi matematis, dan uji analisis regresi untuk mengetahui pengaruh gaya belajar terhadap kemampuan 
komunikasi matematis. Uji analisis ini menggunakan SPSS.

Untuk mengetahui pengaruh gaya belajar visual terhadap kemampuan komunikasi matematis
Menganalisis pengaruh gaya belajar visual terhadap kemampuan komunikasi matematis dengan menggunakan uji regresi sederhana, diperoleh hasil yang dapat dilihat pada tabel berikut.

Tabel 1

Anova Visual

\begin{tabular}{ccccccc}
\hline \multicolumn{2}{l}{ Model } & $\begin{array}{c}\text { Sum of } \\
\text { Squares }\end{array}$ & Df & $\begin{array}{c}\text { Mean } \\
\text { Square }\end{array}$ & F & Sig. \\
\hline \multirow{2}{*}{1} & Regression & 2527.251 & 1 & 2527.251 & 26.063 & $.000^{\mathrm{a}}$ \\
& Residual & 969.665 & 10 & 96.967 & & \\
& & & & & & \\
\hline & Total & 3496.917 & 11 & & & \\
\hline & Berdasarkan & hasil diatas, & & Untuk mengukur besarnya pengaruh
\end{tabular}

diperoleh $\mathrm{F}=26,063$ dengan sig $0,00<$

0,05 yang berarti H0 ditolak, artinya gaya belajar visual terhadap persamaan regresi sederhana gaya belajar visual berpengaruh terhadap kemampuan komunikasi matematis.

Tabel 2

Model Summary Visual

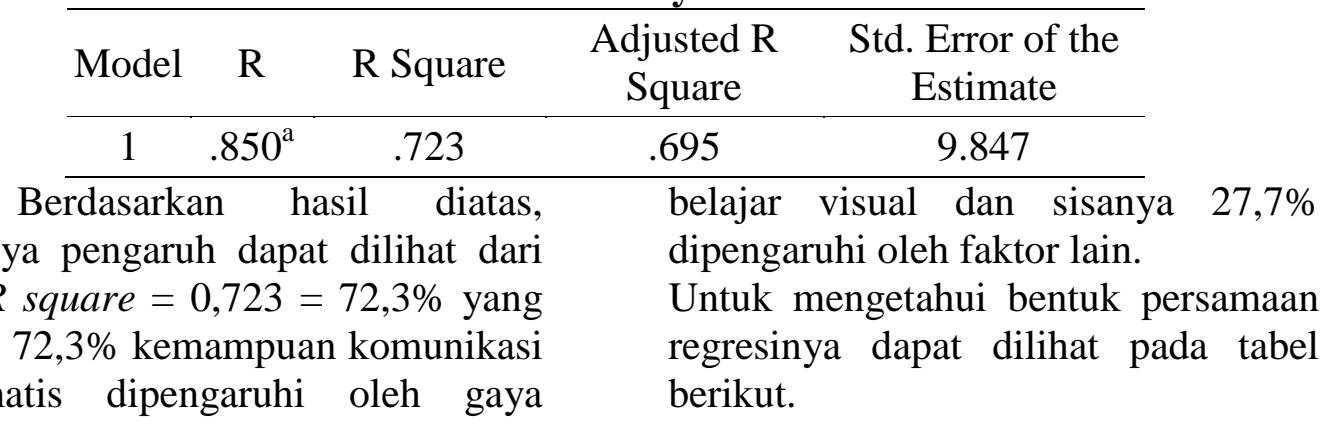

Tabel 3

Coefficients Visual

\begin{tabular}{|c|c|c|c|c|c|c|}
\hline \multirow{2}{*}{ Model } & \multicolumn{2}{|c|}{$\begin{array}{c}\text { Unstandardized } \\
\text { Coefficients }\end{array}$} & $\begin{array}{c}\text { Standardized } \\
\text { Coefficients }\end{array}$ & \multirow{2}{*}{$\mathrm{T}$} & \multirow{2}{*}{ Sig. } \\
\cline { 3 - 6 } & B & Std. Error & Beta & & \\
\hline \multirow{2}{*}{1} & (Constant) & -73.229 & 28.313 & & -2.586 & .027 \\
\cline { 2 - 6 } & X1 & 5.496 & 1.077 & .850 & 5.105 & .000 \\
\hline
\end{tabular}

Berdasarkan hasil diatas, dapat dilihat hubungan gaya belajar visual terhadap kemampuan komunikasi matematis yang ditunjukkan pada persamaan regresi. Bentuk persamaan regresi yaitu $Y^{\wedge}=-73,229+5,496 x$, artinya setiap penambahan variabel gaya belajar visual sebesar satu satuan, maka akan menambah nilai kemampuan komunikasi matematis 
sebesar 5,496, sehingga H0 ditolak dan terima H1. Berdasarkan hal tersebut artinya gaya belajar visual berpengaruh positif terhadap kemampuan komunikasi matematis.

Untuk mengetahui pengaruh
gaya belajar auditorial terhadap

\section{Tabel 4}

Anova Auditoria

\begin{tabular}{|c|c|c|c|c|c|}
\hline Model & $\begin{array}{c}\text { Sum of } \\
\text { Squares }\end{array}$ & df & $\begin{array}{c}\text { Mean } \\
\text { Square }\end{array}$ & $\mathbf{F}$ & Sig. \\
\hline 1 Regression & 3229.748 & 1 & 3229.748 & 21.895 & $.000^{\mathrm{a}}$ \\
\hline Residual & 2065.189 & 14 & 147.514 & & \\
\hline Total & 5294.938 & 15 & & & \\
\hline
\end{tabular}

Berdasarkan hasil tersebut, diperoleh $\mathrm{F}=21,895$ dengan sig $0,00<0,05$ yang berarti H0 ditolak, artinya persamaan regresi sederhana gaya belajar auditorial berpengaruh terhadap kemampuan komunikasi matematis.

Tabel 5

Model Summary Auditorial

\begin{tabular}{ccccc} 
Model & $\mathbf{R}$ & R Square & $\begin{array}{c}\text { Adjusted } \\
\text { R Square }\end{array}$ & $\begin{array}{c}\text { Std. Error of the } \\
\text { Estimate }\end{array}$ \\
\hline 1 & $.781^{\mathrm{a}}$ & .610 & .582 & 12.146 \\
\hline
\end{tabular}

Berdasarkan tabel diatas, besarnya pengaruh dapat dilihat dari nilai $R$ square $=0,610=61 \%$ yang berarti $61 \%$ kemampuan komunikasi matematis dipengaruhi oleh gaya kemampuan komunikasi matematis dengan menggunakan regresi linear sederhana. Menganalisis pengaruh gaya belajar auditorial terhadap kemampuan komunikasi matematis diperoleh hasil yang dapat dilihat pada tabel berikut.
Untuk mengukur besarnya pengaruh gaya belajar auditorial terhadap kemampuan komunikasi matematis dapat dilihat pada tabel berikut.

\section{Tabel 6}

\section{Coefficients Auditorial}

\begin{tabular}{|c|c|c|c|c|c|}
\hline \multirow[t]{2}{*}{ Model } & \multicolumn{2}{|c|}{$\begin{array}{l}\text { Unstandardized } \\
\text { Coefficients }\end{array}$} & \multirow{2}{*}{\begin{tabular}{|c} 
Standardized \\
Coefficients
\end{tabular}} & \multirow[t]{2}{*}{$\mathbf{t}$} & \multirow[t]{2}{*}{ Sig. } \\
\hline & B & Std. Error & & & \\
\hline (Constant) & -31.246 & 22.498 & & -1.389 & 187 \\
\hline $\mathrm{X} 2$ & 3.819 & .816 & .781 & 4.679 & .000 \\
\hline
\end{tabular}

Berdasarkan hasil tabel diatas, auditorial terhadap kemampuan dapat dilihat hubungan gaya belajar komunikasi matematis yang 
ditunjukkan pada persamaan regresi. Bentuk persamaan regresi yaitu $\mathrm{Y}^{\wedge}=$ $31,246+3,819 x$, artinya setiap penambahan variabel gaya belajar auditorial sebesar satu satuan, maka akan menambah nilai kemampuan komunikasi matematis sebesar 3,819, sehingga $\mathrm{H} 0$ ditolak dan terima $\mathrm{H} 1$. Berdasarkan hal tersebut artinya gaya belajar auditorial berpengaruh positif terhadap kemampuan komunikasi matematis.
Untuk mengetahui pengaruh gaya belajar kinestetik terhadap kemampuan komunikasi matematis dengan menggunakan regresi linear sederhana

Menganalisis pengaruh gaya
belajar kinestetik terhadap
kemampuan komunikasi matematis
diperoleh hasil yang dapat dilihat pada
tabel berikut.

Tabel 7

Anova Kinestetik

\begin{tabular}{cccccc}
\hline Model & $\begin{array}{c}\text { Sum of } \\
\text { Squares }\end{array}$ & df & $\begin{array}{c}\text { Mean } \\
\text { Square }\end{array}$ & F & Sig. \\
\hline Regression & 2100.409 & 1 & 2100.409 & 24.197 & $.000^{\mathrm{a}}$ \\
Residual & 1302.062 & 15 & 86.804 & & \\
Total & 3402.471 & 16 & & & \\
\hline
\end{tabular}

Berdasarkan tabel diatas, diperoleh $\mathrm{F}=24,197$ dengan sig 0,00 $<0,05$ yang berarti $\mathrm{H} 0$ ditolak, artinya persamaan regresi sederhana gaya belajar kinestetik berpengaruh terhadap kemampuan komunikasi

\section{Tabel 8}

Model Summary Kinestetik

\begin{tabular}{ccccc}
\hline Model & R & R Square & $\begin{array}{c}\text { Adjusted R } \\
\text { Square }\end{array}$ & $\begin{array}{c}\text { Std. Error of } \\
\text { the Estimate }\end{array}$ \\
\hline 1 & $.786^{\mathrm{a}}$ & .617 & .592 & 9.317 \\
\hline
\end{tabular}

Berdasarkan tabel diatas, besarnya pengaruh dapat dilihat dari nilai Rsquare $=0,617=61,7 \%$ yang berarti $61,7 \%$ kemampuan komunikasi matematis dipengaruhi oleh gaya matematis. Untuk mengukur besarnya pengaruh gaya belajar kinestetik terhadap kemampuan komunikasi matematis dapat dilihat pada tabel berikut. 


\section{Tabel 9}

Coefficients Kinestetik

\begin{tabular}{cccccc}
\hline & \multicolumn{2}{c}{$\begin{array}{c}\text { Unstandardized } \\
\text { Coefficients }\end{array}$} & \multicolumn{2}{c}{$\begin{array}{c}\text { Standardized } \\
\text { Coefficients }\end{array}$} & \\
\cline { 2 - 4 } Model & B & Std. Error & Beta & & Sig. \\
\hline 1(Constant & -30.006 & 21.430 & & -1.400 & .182 \\
X3 & 3.816 & .776 & .786 & 4.919 & .000
\end{tabular}

Berdasarkan tabel dapat dilihat sebesar 3,816, sehingga $\mathrm{H0}$ ditolak hubungan gaya belajar kinestetik terhadap kemampuan komunikasi matematis yang ditunjukkan pada persamaan regresi. Bentuk persamaan regresi yaitu $\mathrm{Y}^{\wedge}=-30,006+3,816 \mathrm{x}$, artinya setiap penambahan variabel gaya belajar kinestetik sebesar satu satuan, maka akan menambah nilai kemampuan komunikasi matematis dan terima H1. Berdasarkan hal tersebut artinya gaya belajar kinestetik berpengaruh positif terhadap kemampuan komunikasi matematis. Untuk menganalisis pengaruh gaya belajar (visual, auditorial dan kinestetik) terhadap kemampuan komunikasi matematis diperoleh hasil yang dapat dilihat pada tabel berikut.

Tabel 10

Anova Gaya Belajar

\begin{tabular}{|c|c|c|c|c|c|}
\hline Model & $\begin{array}{c}\text { Sum of } \\
\text { Squares }\end{array}$ & Df & $\begin{array}{c}\text { Mean } \\
\text { Square }\end{array}$ & $\mathrm{F}$ & Sig. \\
\hline 1 Regression & 7757.708 & 1 & 7757.708 & 73.104 & $.000^{\mathrm{a}}$ \\
\hline Residual & 4563.092 & 43 & 106.118 & & \\
\hline Total & $\begin{array}{r}12320.80 \\
0\end{array}$ & 44 & & & \\
\hline
\end{tabular}

Berdasarkan tabel, diperoleh $\mathrm{F}=$ 73,104 dengan sig $0,00<0,05$ yang berarti $\mathrm{H} 0$ ditolak, artinya persamaan regresi sederhana gaya belajar visual, auditorial dan kinestetik berpengaruh terhadap kemampuan komunikasi matematis.

Untuk mengukur besarnya pengaruh gaya belajar (visual, auditorial dan kinestetik) terhadap kemampuan komunikasi matematis dapat dilihat pada tabel berikut.

\section{Tabel 11}

\section{Model Summary Gaya Belajar}

\begin{tabular}{lrrrr}
\hline Model & $\mathrm{R}$ & $\mathrm{R}$ Square & $\begin{array}{c}\text { Adjusted } \mathrm{R} \\
\text { Square }\end{array}$ & \multicolumn{2}{c}{$\begin{array}{c}\text { Std. Error of the } \\
\text { Estimate }\end{array}$} \\
\hline 1 & $.794^{\mathrm{a}}$ & .630 & .621 & 10.301 \\
\hline
\end{tabular}

Berdasarkan tabel, besarnya pengaruh dapat dilihat dari nilai Rsquare $=0,630=63 \%$ yang berarti 63\% kemampuan komunikasi matematis dipengaruhi oleh gaya belajar kinestetik dan sisanya $37 \%$ dipengaruhi oleh faktor lain. Untuk mengetahui bentuk persamaan regresinya dapat dilihat pada tabel berikut. 
Tabel 12

Coefficients Gaya Belajar

\begin{tabular}{|c|c|c|c|c|c|}
\hline \multirow[t]{2}{*}{ Model } & \multicolumn{2}{|c|}{$\begin{array}{l}\text { Unstandardized } \\
\text { Coefficients }\end{array}$} & \multirow{2}{*}{$\begin{array}{c}\begin{array}{c}\text { Standardized } \\
\text { Coefficients }\end{array} \\
\text { Beta }\end{array}$} & \multirow[t]{2}{*}{$\mathrm{t}$} & \multirow[t]{2}{*}{ Sig. } \\
\hline & $\mathrm{B}$ & Std. Error & & & \\
\hline (Constant) & -37.750 & 13.052 & & -2.892 & .006 \\
\hline$X$ & 4.094 & .479 & .794 & 8.550 & .000 \\
\hline
\end{tabular}

dilihat hubungan gaya belajar visual, auditorial dan kinestetik terhadap kemampuan komunikasi matematis yang ditunjukkan pada persamaan regresi. Bentuk persamaan regresi yaitu $\quad \mathrm{Y}^{\wedge}=-37,750+4,094 \mathrm{x}, \quad$ artinya setiap penambahan variabel gaya belajar visual, auditorial dan kinestetik sebesar satu satuan, maka akan menambah nilai kemampuan komunikasi matematis sebesar 4,094, sehingga $\mathrm{H}_{0}$ ditolak dan terima $\mathrm{H}_{1}$. Berdasarkan hal tersebut artinya gaya belajar visual, auditorial dan kinestetik berpengaruh positif terhadap kemampuan komunikasi matematis.

\section{SIMPULAN DAN SARAN}

\section{Simpulan}

Berdasarkan rumusan masalah, tujuan, hipotesis dan pembahasan, maka dapat disimpulkan bahwa terdapat pengaruh gaya belajar terhadap kemampuan komunikasi matematis mahasiswa

\section{Saran}

Dalam penelitian ini disarankan sebagai berikut: a) mahasiswa sebaiknya lebih aktif lagi dalam proses pembelajarannya untuk meningkatkan kemampuan komunikasi; b) dosen sebaiknya lebih memanfaatkan kemampuan komunikasi mahasiswa baik matematis ataupun yang lain untuk

\section{DAFTAR PUSTAKA}

De Potter, B, dan Hernacki, M. (2007). Quantum Learning : Membiasakan Belajar Nyaman dan Menyenangkan. Bandung : Kaifa.

Nasution. (2008). Berbagai Pendekatan dalam Proses Belajar dan Mengajar. Jakarta: Bumi Aksara.

NCTM. (2000). Principles and Standards for School Mathematics, Reston, Virginia.

NCTM. (1989). Curriculum and Evaluation Standards for School Mathematics. Reston, VA: Authur.

Prastyo, D., S. dkk. (2009). Memahami Jarimatika untuk Pemula. Jakarta: Diva Press.

Prasetyono, D., S. (2009). Yuk Belajar Jarimatika. Yogyakarta: Power Books.

Ramlah, D., F., dan Hamzah, Z. (2014). Pengaruh Gaya Belajar dan Keaktifan Siswa Terhadap Prestasi Belajar Matematika (Survey Pada SMP Negeri di Kecamatan Klari Kabupaten Karawang). Jurnal Ilmiah Solusi Vol.1 No. 3 September Nopember 2014: 68-75

Sumarmo, U. (2000). Pengembangan

Model Pembelajaran

Matematika untuk

Meningkatkan Kemampuan 
Intelektual Tingkat Tinggi Siswa Sekolah Dasar.Research Report at Indonesia University of Education . Unpublished

Suprapto, T. (2009). Pengantar Teori dan Manajemen Komunikasi. Yogyakarta: Medpress 
